\title{
TEKNIK BEDAH DENGAN SKALPEL PADA HIPERPIGMENTASI GINGIVA
}

\author{
Ade Ismail Abdul Kodir*
}

\section{ABSTRACT}

Keywords:

Pigmentation, hyper

pigmentation, melanin depigmentation

Background: Gingival pigmentation is the coloring/staining of the gingiva in the form of a dark purplish color or irregular light brown spots. This staining is derived from melanin granules produced by cells melanoblas. Gingival hyperpigmentation caused by excessive melanin deposition. The cause of this gingival hyperpigmentation is multifactorial : genetic factors, local and systemic. The aims of this article is to overbear the gingival hyperpigmentation with simple techniques, does not require several equipments, but gives contentment results to the patient. Discussion : The gingival melanin hyperpigmentation is not cause medical problems, usually to the point the appearance especially when talking and smiling. Depigmentation is periodontal plastic surgery to remove or reduce gingival hyperpigmentation. There are many ways to eliminate gingival hyperpigmentation, one of them is a surgical using scalpel. Depigmentation surgery does not require any special tools but gives satisfactory results for the patient. Conclusion : Hyperpigmentation gingival surgery techniques can be overcome by using scalpel surgery .
\end{abstract}

\section{PENDAHULUAN}

Jaringan gingiva merupakan salah satu bagian penting dari senyum menawan. Kadang pasien mengeluh adanya pewarnaan pada gingiva yang kurang enak dipandang mata. Hal ini disebabkan gingiva merupakan jaringan dalam rongga mulut yang paling sering terkena dan dapat menimbulkan gangguan penampilan ${ }^{1}$ - Melanin adalah pigmen dasar yang memberi warna pada gingiva. Melanin merupakan pigmen non-hemoglobin yang berasal dari sel melanosit, yang merupakan sel-sel dendrit dari lapisan neuroektodermal yang terletak pada lapisan basal dan spinosum epitel gingival $^{2}$. Melanin berperanan dalam pigmentasi fisiologis dalam rongga mulut. Biasanya dijumpai pada gingiva, palatum durum mukosa dan lidah. Pigmentasi gingiva merupakan pewarnaan pada gingiva berupa warna gelap keunguan atau bercak-bercak coklat terang yang tidak beraturan. Pewarnaan ini berasal dari granula melanin yang di produksi oleh sel-sel melanoblas ${ }^{3}$.

Hiperpigmentasi melanin pada gingiva ini tidak menimbulkan masalah medis, biasanya lebih ke permasalahan penampilan terutama saat bicara dan tersenyum. Kebutuhan perawatan kosmetik ini sudah merupakan hal yang biasa ${ }^{3}$. Depigmentasi merupakan tindakan bedah plastik periodontal untuk melepaskan atau mengurangi hiperpigmentasi gingiva. Banyak cara untuk menghilangkan hiperpigmentasi gingiva, seperti pemakaian bahan kimia, tindakan abrasi dengan menggunakan bor diamond, gingivektomi, autograft jaringan lunak, operasi flap partial, bedah krio, dan pemakaian laser. Hasil yang diperoleh dari macam-macam cara tersebut sangat bervariasi, dan tiap cara ada keuntungan dan kerugiannya ${ }^{4}$.

Salah satu cara depigmentasi yang masih popular adalah pembedahan dengan memakai skalpel. Cara ini meliputi pengambilan epitel gingiva dan selapis jaringan ikat di bawahnya

*Departement Periodonti Fakultas Kedokteran Gigi Universitas Islam Sultan Agung

Korespondesi: ade@unissula.ac.id 
dengan harapan timbulnya penyembuhan jaringan sekunder pada daerah yang sudah diambil tersebut. Akan tetapi tindakan depigmentasi dengan pembedahan menggunakan skalpel ini perlu hati-hati dan gigi di sekitarnya harus dilindungi karena bisa menyebabkan resesi dan kerusakan jaringan periosteum serta tulang di bawahnya. Prosedur depigmentasi dengan pembedahan tidak memerlukan alat khusus tapi cukup memuaskan bagi pasien ${ }^{4}$.

\section{TINJAUAN PUSTAKA}

Senyum adalah adalah expresi dari perasaan senang, kesuksesan, kasih sayang dan rasa hormat yang menambah rasa percaya diri. Keserasian senyuman tidak hanya ditentukan oleh bentuk, posisi dan warna gigi saja, tapi juga oleh jaringan gingivanya. Jaringan gingiva merupakan bagian penting dari senyum menawan. Kadang pasien mengeluh adanya pewarnaan pada gingiva yang kurang enak dipandang mata. Hal ini disebabkan gingiva merupakan jaringan dalam rongga mulut yang paling sering terkena yang dapat menimbulkan gangguan penampilan ${ }^{1}$.

\section{A. Pigmen Melanin, Gingiva dan pigmentasi gingiva}

Melanin adalah pigmen dasar yang memberi warna pada gingiva. Pigmen melanin ini muncul 3 jam begitu bayi lahir pada jaringan rongga mulut, dan pada beberapa kasus tertentu merupakan satusatunya pigmentasi pada tubuh. Melanin merupakan pigmen non-hemoglobin yang berasal dari sel melanosit, yang merupakan sel-sel dendrit dari lapisan neuroektodermal yang terletak pada lapisan basal dan spinosum epitel gingiva. Melanin ini juga terdapat pada sel-sel lain dari jaringan epitel dan jaringan ikat, yaitu melanofag atau melanofor. Diketahui bahwa jaringan yang mengalami pigmentasi terjadi jika granula melanin ini tersintesis oleh melanosit dan di transfer ke sel keratinosit. Hubungan antara melanosit dan keratinosis ini disebut sebagai unit melanin epidermal ${ }^{2}$.

Melanin, karotin dan oxihemoglobin adalah pigmen-pigmen utama yang menyebabkan pemawarnaan fisiologis di dalam rongga mulut. Melanin pigmen coklat alami, yang di produksi oleh melanosit yang terletak di lapisan basal epitel. Derajat pigmentasi ini tergantung dari beberapa faktor, terutama aktifitas melanosit. Derajat pigmentasi gingiva ini ada kaitannya dengan pigmentasi pada kulit. Orang kulit putih cenderung tidak berpigmentasi pada kulitnya ${ }^{5}$. Melanin melindungi DNA dari proses ionisasi yang disebakan oleh radiasi sinar Ultra Violet dan merubahnya menjadi panas melalui proses konversi internal ultrafas. Melanin terdapat pada setiap individu kecuali albino, dimana pigmentasi melanin ini tidak selalu terdeteksi secara klinis. Melanin juga merupakan penentu utama dari adanya pewarnaan jaringan pada manusia, termasuk pada kulit, selaput mukosa, rambut, iris mata dan bagian dari otak. Konsentrasi dan distribusi melanosit pada kulit hampir sama pada setiap individu, sedangkan pola expresinya bisa bervariasi. Intensitas pigmentasi melanin pada kulit merupakan suatu proses adaptasi terhadap penetrasi radiasi sinar Ultra Violet ke dalam lapisan epidermis. Pola pigmentasi melanin ditentukan oleh sisntesis vitamin D3 dan keperluan fotoproteksi serta karakteristi distribusi geografis. Orang yang bertempat tinggal dengan radiasi sinar Ultra Violet yang tinggi memerlukan perlindungan terhadap radiasi UV yang tinggi pula oleh karena itu mempunyai kulit yang lebih gelap dibandingkan dengan orang yang jarang terpajan sinar UV. Pigmentasi melanin pada kulit ini mempunyai fungsi sebagai pelindung terhadap efek merusak akibat radiasi sinar UV seperti luka bakar pada kulit dan keganasan) selain itu juga untuk mencegah fotosilis zat-zat nutrisi ${ }^{6}$.

Gingiva merupakan mukosa fibrosa yang mengelilingi gigi dan melapisi bagian 
koronal tulang alveolar. Gingiva salah satu bagian dari jaringan rongga mulut yang paling mudah mengalami pigmentasi dan paling cepat terlihat secara langsung. Warna gingiva sehat bervariasi mulai dari
Albright, melanoma malignan, selain itu akibat adanya pemakaian antibiotik dalam jangka waktu lama, seperti antimalaria dan antidepresi ${ }^{1}$.

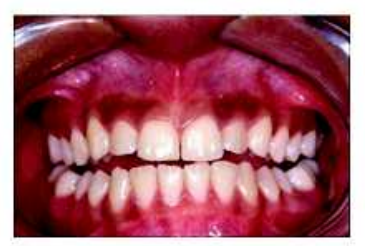

A

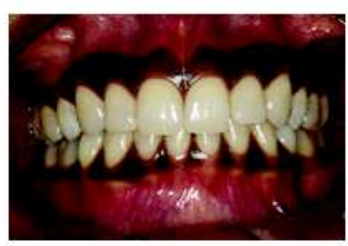

B

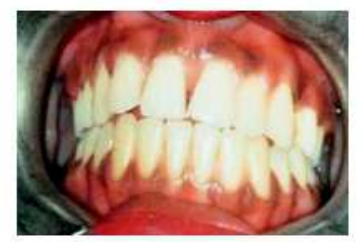

C

Gambar.1. Pigmentasi gingiva, A.Difus, B. Padat, C. Tidak beraturan(bintikbintik atau macula)

merah muda sampai ke biru-biruan. Di antara batas normal ini, semua tergantung dari intensitas melanogenesis, derajat epitelisasi lapisan korneum, kedalaman epitelisasi dan vaskularisasi gingiva.

Warna gingiva tergantung dari beberapa faktor antara lain : jumlah dan ukuran pembuluh darah, ketebalan epithelium, derajat keratinisasi dan jumlah pigmen ${ }^{5}$.

Melanin berperanan dalam pigmentasi fisiologis dalam rongga mulut. Biasanya dijumpai pada gingiva, palatum durum mukosa dan lidah. Gambaran klinis bisa difus (gambar 1A), padat (gambar 1B) atau tidak beraturan/berupa bintik-bintik atau macula (gambar $1 \mathrm{C}$ ), Dengan variasi warna mulai dari coklat muda sampai kehitam-hitam ${ }^{6}$.

Pigmentasi gingiva merupakan pewarnaan pada gingiva berupa warna gelap keunguan atau bercak-bercak coklat terang yang tidak beraturan. Pewarnaan ini berasal dari granula melanin yang di produksi oleh sel-sel melanoblas ${ }^{2}$ Hiperpigmentasi gingiva disebabkan oleh deposisi melanin yang berlebihan. Penyebab hiperpigmentasi gingiva ini bersifat multifaktorial, yaitu : faktor genetik, lokal dan sistemik. Ada beberapa contoh penyebab pigmentasi ini, antara lain pemakaian tembakau, gangguan sistemik seperti gangguan hormonal, sindrom

\section{B. Penatalaksanaan Hiperpigmentasi Gingiva}

Hiperpigmentasi melanin pada gingiva ini tidak menimbulkan masalah medis, biasanya lebih ke permasalahan penampilan terutama saat bicara dan tersenyum. Kebutuhan perawatan kosmetik ini sudah merupakan hal yang biasa $^{3}$.

Banyak prosedur untuk menghilangkan hiperpigmentasi gingiva, seperti pemakaian bahan kimia, tindakan abrasi dengan menggunakan bor diamond, gingivektomi, autograft jaringan lunak, operasi flap partial, bedah krio, dan pemakaian laser (Tabel 1). Hasil yang diperoleh dari macam-macam teknik tersebut sangat bervariasi, dan tiap teknik ada keuntungan dan kerugiannya. Menurut Dummet dan Bolden pada tahun 1963 hiperpigmentasi gingiva dengan gingivektomi pada 9 kasus, timbul repigmentasi pada $66,66 \%$ kasus pada hari ke 33 sampai 120 hari. Prosedur depigmentasi yang dilakukan oleh Sameer tahun 2006 pada 3 kasus dengan tindakan abrasi menggunakan bor diamon kecepatan tinggi, timbul repigmentasi pada bulan ke $18^{4}$.

Depigmentasi gingiva dengan bahan kimia seperti campuran antara Fenol 90 $\%$ dan alcohol $95 \%$ digunakan untuk menghancurkanjaringan sampai ke bawah 
Tabel 1. Macam-macam teknik depigmentasi gingiva

I. Metode dengan tujuan pengambilan lapisan pigmen
A. Tindakan bedah
a. Teknik bedah dengan scalpel
b. Bedah krio
c. Bedah elektrik
d. Laser

- Neodymiun: Alumunium-Yttrium-Gamet (Nd:YAG)

- Erbiium:YAG(Er:YAG)

- Carbon Dioxide (CO2)

B. Depigmintasi dengan bahan kimia memakai bahan-bahan caustic (tidak lagi dipakai)

II. Metode dengan cara menutupi pigmentasi gingival dengan graft Free gingival graft

$$
\text { A. Acellular Dermal Matrix Allograft }
$$

lapisan sel basalis, tetapi bahan kimia ini sangat berbahaya bagi jaringan mulut dan cepat timbul repigmentasi. Graft gingiva bebas yang memerlukan penambahan tempat pembedahan bisa dilakukan, tetapi kadang timbul permasalahan pada penentuan warna gingiva ${ }^{7}$. Depigmentasi dengan cara bedah krio serta laser, memerlukan keahlian yang tinggi dan peralatan khusus ${ }^{8}$.

Salah satu prosedur yang depigmentasi yang masih popular adalah prosedur pembedahan dengan memakai skalpel. Prosedur ini meliputi pengambilan epitel gingiva dan selapis jaringan ikat di bawahnya dengan harapan timbulnya penyembuhan jaringan sekunder pada daerah yang sudah diambil tersebut. Epitel baru yang terbentuk biasanya tanpa pigmentasi melanin. Akan tetapi tindakan pigmentasi dengan pembedahan menggunakan skalpel ini perlu hati-hati dan gigi di sekitarnya harus dilindungi karena tindakan yang kurang hati-hati bisa menyebabkan resesi dan kerusakan jaringan periosteum serta tulang di

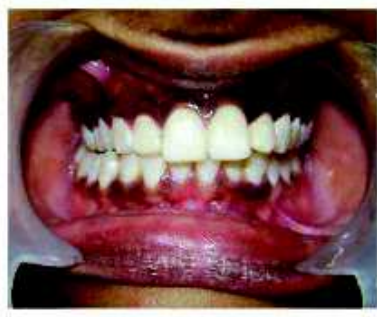

A

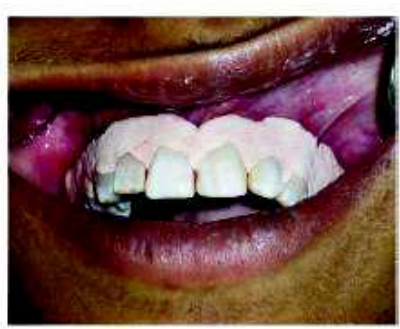

D

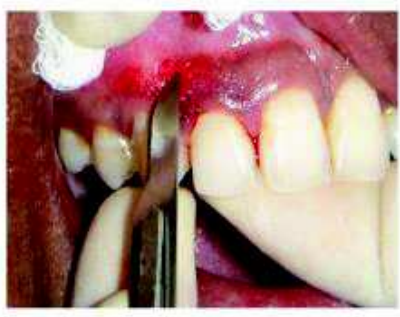

B

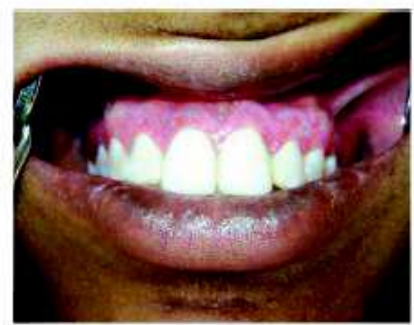

E

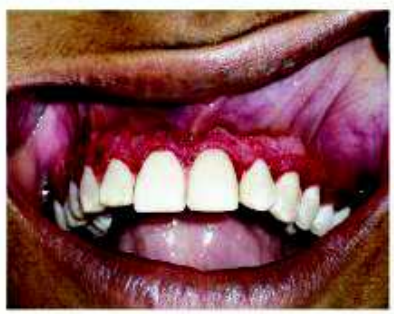

C

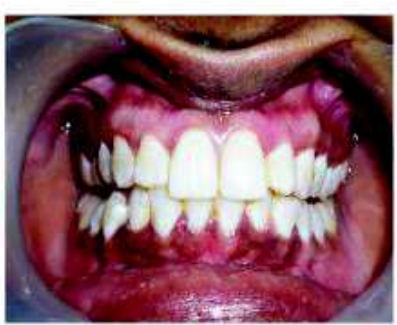

F

Gambar 2. Depigmentasi dengan pembedahan. A. Sebelum operasi, B. Skalpel No.15 digunakan untuk pengambilan lapisan epitel pada gingiva bagian anterior RA, C.Lapisan pigmentasi sudah terambil, D. Penutupan daerah operasi dengan periodontal dressing, E. 1 minggu pasca operasi, F. 6 bulan pasca operasi. 
bawahnya. Pada penelitian terbaru prosedur depigmentasi ini dilakukan dengan menggunakan pisau gingivektomi Kirkland untuk mengetahui durasi dan intensitas repigmentasi. Tindakan ini cukup sederhana, aman dan non agresif serta mudah diulang bila dikehendaki ${ }^{4}$.

\section{Prosedur Depigmentasi dengan Pembedahan}

Prosedur depigmentasi dengan pembedahan tidak memerlukan alat khusus tapi cukup memuaskan bagi pasien. Contoh kasus dengan pigmentasi gingiva yang meliputi gingiva mulai dari premolar satu kanan sampai premolar satu kiri (gambar.2A) Tindakan dilakukan dengan menggunakan skalpel dan abrasi dengan menggunakan bor. Tahapan prosedur diterangkan kepada pasien dan informed consent. Kemudian dilakukan pencatatan tentang riwayat medis, riwayat keluarga serta pemeriksaan darah untuk mengantisisipasi adanya kontraindikasi. Selanjutnya dilakukan tindakan anastesi infiltrasi pada regio antara premolar satu kanan sampai premolar kiri. Lapisan pigmentasi diambil dengan menggunakan skalpel No. 15 dan bor diamond (gambar 2B). Perdarahan ditanggulangi dengan penekanan memakai kasa steril yang direndam anastesi lokal. Setelah pengambilan seluruh epitel yang terpigmentasi dan selapis jaringan ikat di bawahnya dengan skalpel, kemudian dilakukan tindakan abrasi dengan menggunakan bor diamond untuk mendapatkan kontur gingiva fisiologis. Pengeboran ini dilakukan dengan tekanan ringan dan gerakan seperti menyikat gigi serta dilakukan tidak pada satu tempat. Tindakan juga harus hati-hati sampai semua lapisan pigmen terambil (gambar 2C). Selanjutnya dilakukan irigasi dengan menggunakan larutan salin dan penutupan luka dengan periodontal dressing (gambar 2D). Pada tahap akhir diresepkan pemberian antibiotik dan analgetik sehari tiga kali selama 5 hari dan pasien disarankan untuk memakai obat kumur khlorhexidin dua kali sehari selama satu minggu. Kontrol dilakukan seminggu kemudian, tampak proses penyembuhan luka baik dan pasien tidak mengeluh sakit (gambar 2E). Pemakaian obat kumur dilanjutkan untuk satu minggu berikutnya. Pada kunjungan 6 bulan berikutnya tampak penyembuhan yang baik serta timbul reepitelisasi dan pasien tidak mengeluh adanya rasa sakit serta sensitive (gambar $2 \mathrm{~F})^{9}$.

\section{DISKUSI}

Hiperpigmentasi gingiva yang penyebabnya multifaktorial, walaupun tidak menimbulkan masalah medis, tapi kadang sangat mengganggu penampilan seseorang. Oleh karena itu sering pasien datang ke klinik perawatan gigi untuk menghilangkan keluhan ini.

Ada banyak cara yang bisa dilakukan untuk menangani hiperpigmentasi melanin ini, mulai dengan tindakan yang sederhana, pemakaian bahan-bahan kimia tertentu, sampai dengan pemakaian laser yang memerlukan keterampilan operator tinggi serta dukungan dari peralatan yang canggih. Dari berbagai macam cara ini, tidak ada satupun yang paling baik dari segala segi, karena masing-masing ada keunggulan dan kekurangannya.

Depigmentasi dengan pembedahan menggunakan skalpel walaupun caranya cukup sederhana, tidak terlalu sulit dan tidak memerlukan banyak peralatan, tetap memerlukan ketelitian dan pengalaman operator. Sebab kalau kurang hati-hati bisa menyebabkan resesi dan kerusakan jaringan periosteum dan tulang di bawahnya.

Repigmentasi adalah timbul kembali dari pigmentasi melanin pada gingiva yang sudah dilakukan depigmentasi. Hal ini bisa terjadi dalam jangka waktu tertentu, area tertentu, dan bentuk yang walaupun itu berupa titik atau bercak, sudah merupakan repigmentasi. Kemungkinan terjadinya repigmentasi ini 
perlu dikemukakan pada pasien, sebelum tindakan depigmentasi dilakukan. Namun walaupun tindakan pembedahan dengan skalpel ini bisa juga terjadi repigmentasi, hasil yang diperoleh memuaskan pasien dan repigmentasi dapat terjadi dalam waktu yang cukup lama.

\section{KESIMPULAN}

Teknik bedah dengan menggunakan skalpel dapat mengoreksi hiperpigmentasi gingiva dan memuaskan bagi pasien. Cara sederhana, relatif mudah dilakukan, murah serta tidak memerlukan banyak peralatan. Kekurangan dari pemakaian skalpel yaitu adanya perdarahan yang cukup banyak. Oleh karena itu perlu keterampilan operator dan kerjasama pasien dalam memelihara kebersihan mulutnya selama proses penyembuhan. Pasien hendaknya diberitahu tentang kemungkinan adanya kekambuhan (repigmentasi).

\section{DAFTAR PUSTAKA}

1. Kanakamedala, A.K., Geetha, A., Ramakrishnan, T., and Emadi, P. Management of Gingival Hyperpigmentation by the Surgical Scalpel Technique - Report of three cases. Journal of Clinical and Diagnostic Research. 2010. April (4). Pg. 2341 - 2346.

2. Ponnaiyan, D., Jegadeesan, V., Perumal G., and Anusha, A.Correlating Skin Color with Gingival Pigmentation Patterns in South Indians - A Cross Sectional Study. OHDM. 2014. Vol 13 No. 1 March. Pg. 132-136

3. Javali, M.A., Tapashetti, R., and Deshmukh, J. Esthetic Management of Gingival Hyperpigmentation : Report of Two Cases. International Journal of Dental Clinics. 2011 : Vol 3(2), pg 115-116.

4. Kaur, H., Jain, S., Sharma, R.L. Duration Of Reappearance Of Gingival Melanin Pigmentation After Surgical Removal - A Clinical study. Journal of Indian Society of Periodontology. 2010, Vol. 14 (2) pg. 101-105

5. Balcheva, G., and Balcheva M. Depigmentasion of Gingiva. Journal of IMAB. 2014. Vol. 20, Issue 1, pg : 487-489

6. Karydis, A., Bland, P., and Shiloah, J. Management of Oral Melanin Pigmentation. Journal of The Tennessee Dental Association. 2012. Vol.92 (2). Pg. 10-15.

7. Shah, C., Dave, R., Shah, M., and Dave, D. Evaluation of Scalpel Versus Dioda Laser for
Gingival Depigmentation : A Case Report. International Journal of Advanced Health Sciences. 2014. Vol. 1 (2). Pg. 24-27

8. Humagain, M., Nayak, D.G., and Uppoor A.S. Gingival Depigmentation : A Case Report with Review of Literature. Journal of Nepal Dental Association. 2009. Vol. 10 (1). Pg 53-56.

9. Prasad, S.S.V., Agrawal, N., and Reddy, N.R. Gingival Depigmentation : A Case Report. People's Journal of Scientific Research. 2010. Vol. 3 (1). Pg. 27-29 